https://dx.doi.org/10.4314/jpb.v17i2.1

Vol. 17 no. 2, pp. 81-87 (September 2020)

http://ajol.info/index.php/jpb
Journal of

PHARMACY AND

BIORESOURCES

\title{
Anti-nociceptive and anti-inflammatory effects of the hydroethanolic extract of a polyherbal preparation (Cov-Pla 2) in laboratory animals
}

\author{
Kennedy Iliya AMAGON ${ }^{1,2 *}$, Kakjing Dadul FALANG ${ }^{1,2}$, Bukata Bayero BUKAR ${ }^{1,2}$, Ukpe \\ AJIMA ${ }^{1,3}$, Noel Nen'man WANNANG ${ }^{1,2}$, Jacob Adegboyega KOLAWOLE ${ }^{1,3}$, James \\ Garba DAMEN ${ }^{1,4}$, Yusuf Amuda AGABI ${ }^{1,5}$, Richard Joseph KUTSHIK ${ }^{1,6}$, Ishaya Yohanna \\ LONGDET $^{1,6}$, Simji Samuel GOMEREP ${ }^{1,7}$, Ismaila SHITTU ${ }^{1,8}$, Stephen Daniel DAVOU ${ }^{1,9}$ \\ ${ }^{1}$ Plateau State Research Team on Covid-19 and Other Infectious Diseases, Jos, Plateau State, Nigeria. \\ ${ }^{2}$ Department of Pharmacology \& Toxicology, Faculty of Pharmaceutical Sciences; ${ }^{3}$ Department of Pharmaceutical \\ \& Medicinal Chemistry, Faculty of Pharmaceutical Sciences; ${ }^{4}$ Department of Medical Laboratory Sciences, \\ Faculty of Health Sciences and Technology; ${ }^{5}$ Virology Unit, Department of Microbiology, Faculty of Natural \\ Sciences; ${ }^{6}$ Department of Biochemistry, Faculty of Basic Medical Sciences; ${ }^{7}$ Infectious Diseases Unit, Department \\ of Medicine, Faculty of Clinical Sciences; University of Jos, Nigeria. \\ ${ }^{8}$ National Veterinary Research Institute, Vom, Plateau State, Nigeria. \\ ${ }^{9}$ Plateau State Ministry of Health, Jos, Plateau State, Nigeria.
}

Received 1 $1^{\text {th }}$ August 2020; Accepted $3^{\text {rd }}$ September 2020

\begin{abstract}
Symptoms of Coronavirus Disease-2019 include pulmonary hyper-inflammation; managing local and systemic inflammatory responses may be key in treatment. This study evaluated the anti-inflammatory, analgesic and antipyretic effects of a mixture ( $\mathrm{Cov}$-Pla 2) containing five medicinal plants in laboratory animals. The antinociceptive activity of Cov-Pla 2 was evaluated using acetic acid-induced writhing, Brewer's Yeast Pyrexia test in rats and hot plate tests in mice. The egg albumin-induced rat paw oedema test was employed to evaluate the extract's anti-inflammatory activity. The extract produced a dose-dependent $(125-500 \mathrm{mg} / \mathrm{kg}$, p.o. $)$ inhibition of pain response elicited by acetic acid, compared to normal saline and increased reaction latency in the hot plate test. The antiinflammatory test showed a significant $(P<0.05)$ reduction in paw size diameter at $125 \mathrm{mg} / \mathrm{kg}$ from 2 hours, compared to control. In the antipyretic test, the extract produced a significant $(P<0.05)$ time-dependent decrease in rectal temperature at $125 \mathrm{mg} / \mathrm{kg}$ after 2 and 3 hours and at 250 and $500 \mathrm{mg} / \mathrm{kg}$ after 3 hours, compared to normal saline. The extract did not produce mortality up to $5000 \mathrm{mg} / \mathrm{kg}$ per oral. The results indicated that the extract possesses antinociceptive and anti-inflammatory properties, which support its recommendation for trials in the treatment of symptoms associated with COVID-19.
\end{abstract}

Keywords: COVID-19; Inflammation; Nociception; Polyherbal; SARS-CoV-2

${ }^{*}$ Correspondence. E-mail: pharmken@gmail.com Tel: +234-8095550056.

ISSN 0189-8442

(cc) EY-NC 2020. Published by Faculty of Pharmaceutical Sciences, University of Jos, Nigeria. Under Creative Commons Attribution-NonCommercial 4.0 International License. https://creativecommons.org/licenses/by-nc/4.0/ 


\section{INTRODUCTION}

Coronavirus disease-19 (COVID-19) caused by Severe Acute Respiratory Syndrome Corona Virus-2 (SARS-CoV-2) has caused a pandemic that has overwhelmed health care systems globally $[1,2]$. Currently, no specific effective treatment for COVID-19 exists. COVID-19 is characterized by a wide spectrum of symptoms including abdominal pain, fever, cough, headache, diarrhea, tiredness, runny nose, sore throat and vomiting, while loss of smell or taste is experienced by some people [3,4]. Respiratory problems such as shortness of breath or difficult breathing, viral pneumonia and respiratory failure have also been reported. Recently, an inflammatory syndrome has been reported in some patients [5]. SARS-CoV-2 is reported to trigger a cell death-induced "eicosanoid storm", that involves prostaglandins and leukotrienes, which in turn initiates a robust inflammatory response [6].

The global public health threat caused by the coronavirus disease ignited a lot of scientific search for a cure. This resulted in several formulations, one of which is Cov-Pla 2. This formulation contains parts of 5 plants African ethnopharmacological relevance with bioactivity against microbes, including viruses [7]. Polyherbal preparations offer disease therapy a near holistic approach [8]. This crucial traditional therapeutic herbal approach involves combining several medicinal herbs to accomplish desired therapeutic efficacy [9]. The concept of Ayurvedism that wellness depends on a delicate balance of the mind, body and spirit provides that in order to obtain the desired therapeutic effect, different plant phytochemicals need to be combined, as the active phytochemical constituents of individual plants may be insufficient [9].

Plants, containing medicinal compounds or phytochemicals, have been used for different purposes over time, including the relief of pain and inflammation $[10,11]$. Considering the fact that analgesic drugs like salicylic acid and morphine were originally derived from plants, the utilization of plants with anti-nociceptive and anti-inflammatory properties for treating diseases with symptoms of pain and inflammation would be considered a productive strategy.

The aim of this study was to evaluate the antinociceptive and anti-inflammatory activities of the hydroethanolic extract of Cov-Pla 2 polyherbal preparation in rodents.

\section{EXPERIMENTAL}

Test animals. Three-week old albino rats (140-200 g) and mice (20-30 g) of both sexes were purchased from the Animal Experimental Unit, Department of Pharmacology and Toxicology, University of Jos, Nigeria. The animals were kept at room temperature $(27 \pm$ $2^{\circ} \mathrm{C} ; 70-80 \%$ humidity; $12 \mathrm{~h}$ light/dark cycle) in the Animal Experimental Unit, Department of Pharmacology and Toxicology, University of Jos, Nigeria for at least $48 \mathrm{~h}$ prior to the procedure. Commercial food pellets (Livestock Feeds, Nigeria Ltd) and water were supplied ad libitum. Animal experimental protocols were in accordance with the current guidelines for the care and use of laboratory animals [12]. Approval to conduct the study was given by the Animal Ethics Committee of the Department of Pharmacology and Toxicology, University of Jos, Nigeria under the ethical certificate number F17.00379 dated $5^{\text {th }}$ June, 2020.

Drugs and Chemicals. Distilled water, Normal saline $0.9 \%$ w/v, Diclofenac Sodium (Novartis, $20 \mathrm{mg} / \mathrm{kg}$ ), Morphine (Sterop Pharma, Belgium), Acetic acid $0.6 \%$ (M\&B), Formalin $1 \%$ (B\&B), Brewer's Yeast (ICH), Acetylsalicylic acid $300 \mathrm{mg}$ (Sigma) and Egg white from eggs purchased at a local poultry.

Collection and preparation of plant materials. The plants were identified by $\mathrm{Mr}$. Joseph Ajila, a taxonomist at the Federal College of Forestry, Jos, Nigeria. Voucher 
specimens were deposited at the herbarium of the institute. One thousand grams (1000 g of the dried parts of the different plants were then pulverized, mixed together and macerated in $10 \mathrm{~L}$ of hydroethanol (3 liters water to 7 liters $70 \%$ ethanol) for $24 \mathrm{~h}$. The mixture was thereafter decanted, filtered and the residue was re-macerated in $1000 \mathrm{~mL}$ hydroethanol for $24 \mathrm{~h}$. This process was repeated two more times to ensure exhaustive extraction. At the end of the extraction process, the combined filtrate was evaporated to dryness under reduced pressure at $40^{\circ} \mathrm{C}$. A dark brownish solid extract with a yield of $15.4 \%$ was obtained. The solid extract was reconstituted in distilled water to give appropriate concentrations before administration to experimental animals.

Acute toxicity test (LD50 Determination). The method of Lorke was used to estimate acute toxicity [13]. Briefly, three groups containing three mice each were fasted for 12 $\mathrm{h}$ before the test and administered the extract orally at the dose of $10 \mathrm{mg} / \mathrm{kg}, 100 \mathrm{mg} / \mathrm{kg}$ and $1000 \mathrm{mg} / \mathrm{kg}$ respectively. The mice were observed over a period of $24 \mathrm{~h}$ for morbid signs and mortality. In the second phase, another three animals were divided into three groups with one animal each and administered 1600 $\mathrm{mg} / \mathrm{kg}, 2900 \mathrm{mg} / \mathrm{kg}$ and $5000 \mathrm{mg} / \mathrm{kg}$ of the extract respectively and then observed for $24 \mathrm{~h}$ for behavior as well as mortality.

Screening for anti-inflammatory activity. (a) Egg albumin-induced rat paw oedema test. Treatment with normal saline $(10 \mathrm{~mL} / \mathrm{kg}$, p.o. $)$, standard drug, diclofenac $(20 \mathrm{mg} / \mathrm{kg})$ and extract $(125,250,500 \mathrm{mg} / \mathrm{kg}$, p.o. $)$, were administered to five groups of five rats each. One hour post-treatment, oedema was induced by injection of egg albumin (from fresh hen's egg) $(0.1 \mathrm{~mL}, 0.01 \mathrm{~g} / \mathrm{mL}$ saline $)$ into the subplantar tissue of the right hind paw. The linear paw circumference was then measured using a digital vernier caliper. Linear paw circumferences of the rats were determined just before injection of the phlogistic agent and at 30-min intervals for $3 \mathrm{~h}$ [14]. The percent inhibition of inflammation was calculated using the formula [15]:

$$
\% \text { inhibition }=100(1-\mathrm{Vt} / \mathrm{Vc}) \text {, }
$$

where $\mathrm{Vc}$ represents oedema volume in control and $\mathrm{Vt}$ the oedema volume in the test groups.

\section{Screening for antinociceptive activity}

(a) Acetic acid induced writhing in mice. Mice (20-30 g) fasted overnight were divided into five groups of five animals each. The animals were then treated with normal saline $0.9 \% \mathrm{w} / \mathrm{v}(10 \mathrm{~mL} / \mathrm{kg}$, p.o.) (control group), extract $(125,250,500 \mathrm{mg} / \mathrm{kg}$, p.o. $)$ and diclofenac $(20 \mathrm{mg} / \mathrm{kg}$, s.c. $)$. Thirty minutes post oral and subcutaneous administration; test animals were administered acetic acid $(0.6 \%$ $\mathrm{v} / \mathrm{v}, 0.1 \mathrm{~mL} / \mathrm{kg}$, i.p.). The number of writhes (characterized by contraction of the abdominal musculature and extension of the limbs) was then counted for 20 minutes at 5-minute intervals [16].

(b) Hot plate test in mice. Albino mice used in this experiment were initially screened by placing the animals in turn on a hot plate (Stuart Model US150) set at $50 \pm 0.5^{\circ} \mathrm{C}$ [17], and animals which failed to lick the hind paw or jump (nociceptive responses) within $15 \mathrm{~s}$ were not used for this study. Eligible animals (20-30 g) were divided into five groups of five mice each, and the pretreatment reaction time for each mouse was determined. Mice in different groups were then treated with normal saline $0.9 \% \mathrm{w} / \mathrm{v}(10 \mathrm{~mL} / \mathrm{kg}$, p.o.) (control group), extract $(125,250,500 \mathrm{mg} / \mathrm{kg}$, p.o.), and morphine (1 mg/kg, s.c.) (standard drug). The reaction time of each mouse was then determined at 5 minutes before administration of test agents and 30,60, and 90 minutes after administration. A cut-off time of $30 \mathrm{~s}$ was used [18].

(c) Antipyretic test in rats (Brewer's yeast pyrexia model). Antipyretic activity in albino rats was evaluated with induction of fever by $20 \%$ Brewer yeast $(1 \mathrm{mg} / \mathrm{kg})$. Albino rats (140-200 g) appropriately restrained had their rectal temperature measured by inserting a digital thermometer into the rectum. Pyrexia 
was induced by subcutaneously injecting 1 $\mathrm{mg} / \mathrm{kg}$ of a $20 \%$ suspension of Brewer yeast. After $18 \mathrm{~h}$ of yeast injection, the rats which showed a rise in temperature of at least $1^{\circ} \mathrm{F}$ $\left(0.6^{\circ} \mathrm{C}\right)$ were taken for the study. Twenty-five of the rats that showed this temperature increase were then divided into five groups ( $\mathrm{n}$ $=5$ ). Animals in group 1 received normal saline $0.9 \% \mathrm{w} / \mathrm{v}(10 \mathrm{~mL} / \mathrm{kg}$, p.o. $)$, group $2 \mathrm{had}$ the standard drug, aspirin (300 mg/kg p.o.), and groups 3, 4 and 5 received the extract (125, 250, $500 \mathrm{mg} / \mathrm{kg}$, p.o.). Temperatures were measured and recorded 5 minutes before and 1 $\mathrm{h}, 2 \mathrm{~h}, 3 \mathrm{~h}$ and $4 \mathrm{~h}$ post-extract, aspirin and normal saline administrations [19].

Statistical analysis. Data are presented as mean \pm Standard Error of the Mean (SEM). Statistical analysis was done using Student's $t$ test and two-way ANOVA, using GraphPad Prism 5 software (GraphPad Software, Inc., La Jolla, CA, USA). Results were considered significant between test groups and control at $P<0.05$.

\section{RESULTS}

Acute toxicity testing (LD50 determination). Acute toxicity testing showed that the extract did not cause any mortality up to $5000 \mathrm{mg} / \mathrm{kg}$ (Table 1).

Anti-inflammatory effect of hydroethanolic extract of Cov Pla-2 on egg albumin-induced inflammation in rats. Results in table 4 below show a reduction in paw circumference $(P>0.05)$ from $1.5 \mathrm{~h}$ up to $3 \mathrm{~h}$ postadministration at $125-500 \mathrm{mg} / \mathrm{kg}$, compared to animals administered normal saline.

Effects of the hydroethanolic extract of CovPla 2 on acetic acid-induced abdominal writhing in mice. Results showed that the extract at all doses $(125-500 \mathrm{mg} / \mathrm{kg})$ caused a decrease in number of writhing, compared to animals administered normal saline. Diclofenac (a standard drug) produced a significant decrease $(P<0.05)$ compared to control (Table 2).
Effects of hydroethanolic extract of Cov-Pla 2 on reaction time in the hot plate test in mice. The result in table 3 shows a dosedependent increase $(250-500 \mathrm{mg} / \mathrm{kg})$ in reaction time after 60 and 90 minutes postadministration, compared to the animals administered normal saline.

Effects of hydroethanolic extract of Cov-Pla 2 on rectal temperature in Brewer's yeastinduced pyrexia in rats. The extract reduced rectal temperature at $125 \mathrm{mg} / \mathrm{kg}$ after 2 and 3 hours and at 250 and $500 \mathrm{mg} / \mathrm{kg}$ post administration, in a significant manner $(P<0.05)$, when compared to normal saline.

\section{DISCUSSION}

The safety evaluation of medicinal plants in laboratory animals is a useful tool in predicting their toxicity in humans. In this present study, no mortality was observed up to $5000 \mathrm{mg} / \mathrm{kg}$ body weight in test animals (Table 1), which is an indication of its relative safety at the doses used.

The writhing test is simple, reliable and affords rapid evaluation of antinociceptive activity [20]. The dose-dependent $(125-500 \mathrm{mg} / \mathrm{kg})$ inhibition of the acetic acid induced writhing by the extract (Cov Pla-2) is suggestive of its antinociceptive activity, which might be peripherally mediated. This is based on the association of the model with stimulation of peripheral receptors, especially the local peritoneal receptors at the surface of cells lining the peritoneal cavity [21]. Result of the writhing test from this present study corresponds to the report of a previous study [22]. The abdominal constrictions response induced by acetic acid is a sensitive procedure to evaluate peripherally acting analgesics. The acetic acid induced writhing test is useful for the evaluation of mild, anti-nociceptive, nonsteroidal anti-inflammatory drugs [23]. Acetic acid causes pain generally by releasing endogenous substances such as serotonin, histamine, prostaglandins, bradykinins and substances, which stimulate nerve endings. 
Table 1: Acute Toxicity Testing ( $\mathrm{LD}_{50}$ Determination)

\begin{tabular}{cccc}
\hline Phase & Dose $(\mathrm{mg} / \mathrm{kg})$ & No. of Animals & Mortality \\
\hline 1 & 10 & 1 & 0 \\
1 & 100 & 1 & 0 \\
1 & 1000 & 1 & 0 \\
2 & 1600 & 3 & 0 \\
2 & 2900 & 3 & 0 \\
2 & 5000 & 3 & 0 \\
\hline
\end{tabular}

Table 2: Effects of hydroethanolic extract of Cov-Pla 2 on acetic acid-induced abdominal writhing in mice

\begin{tabular}{lccc}
\hline Group/Treatment & Dose $(\mathrm{mg} / \mathrm{kg})$ & Number of writhings (per 20 min) & \% Inhibition \\
\hline 1 (Normal Saline) & $10 \mathrm{~mL} / \mathrm{kg}$ & $43.00 \pm 8.51$ & 0 \\
2 (Diclofenac) & 20 & $4.80 \pm 3.09^{\mathrm{b}}$ & 88.8 \\
3 (Extract) & 125 & $35.40 \pm 14.17$ & 17.7 \\
4 (Extract) & 250 & $29.20 \pm 10.82$ & 32.1 \\
5 (Extract) & 500 & $28.60 \pm 5.01^{\mathrm{a}}$ & 33.5 \\
\hline
\end{tabular}

$\mathrm{n}=5 ; \quad{ }^{\mathrm{a}} \mathrm{P}<0.05$ compared to morphine; ${ }^{\mathrm{b}} P<0.05$ compared to normal saline; $\quad$ Data presented as mean $\pm \mathrm{SEM}$

Table 3: Effect of hydroethanolic extract of Cov-Pla 2 on reaction time in the hot plate test in mice

\begin{tabular}{llllll}
\hline Group/Treatment & $($ Dose $\mathrm{mg} / \mathrm{kg})$ & $0 \mathrm{~min}$ & $30 \mathrm{~min}$ & $60 \mathrm{~min}$ & $90 \mathrm{~min}$ \\
\hline 1 (Normal saline) & $10 \mathrm{~mL} / \mathrm{kg}$ & $7.64 \pm 0.55$ & $7.72 \pm 0.66$ & $8.38 \pm 0.68$ & $7.28 \pm 1.05$ \\
2 (Morphine) & 1 & $6.66 \pm 0.77$ & $14.40 \pm 4.00$ & $17.72 \pm 5.60$ & $13.11 \pm 1.77^{\mathrm{b}}$ \\
3 (Extract) & 125 & $4.00 \pm 0.15^{\mathrm{ab}}$ & $5.76 \pm 0.45^{\mathrm{b}}$ & $7.22 \pm 0.43$ & $9.84 \pm 1.47$ \\
4 (Extract) & 250 & $4.14 \pm 0.28^{\mathrm{ab}}$ & $8.48 \pm 1.40$ & $9.90 \pm 1.31$ & $10.46 \pm 3.21$ \\
5 (Extract) & 500 & $3.60 \pm 0.53^{\text {ab }}$ & $8.48 \pm 1.75$ & $10.00 \pm 2.15$ & $9.00 \pm 2.21$ \\
\hline
\end{tabular}

Table 4: Anti-inflammatory effect of hydroethanolic extract of Cov-Pla 2 on egg albumin-induced inflammation in rats

\begin{tabular}{lllllllll}
\hline Group/ Treatment & $\begin{array}{l}\text { Dose } \\
(\mathrm{mg} / \mathrm{kg})\end{array}$ & $0 \mathrm{~min}$ & $0.5 \mathrm{~h}$ & $1 \mathrm{~h}$ & $1.5 \mathrm{~h}$ & $2 \mathrm{~h}$ & $2.5 \mathrm{~h}$ & $3 \mathrm{~h}$ \\
\hline 1 Normal saline & $10 \mathrm{~mL} / \mathrm{kg}$ & $5.28 \pm 0.13$ & $7.93 \pm 0.24$ & $8.09 \pm 0.27$ & $7.88 \pm 0.22$ & $7.57 \pm 0.32$ & $7.14 \pm 0.21$ & $6.95 \pm 0.25$ \\
\hline 2 Diclofenac & 20 & $5.19 \pm 0.05$ & $7.52 \pm 0.07$ & $7.52 \pm 0.12$ & $6.90 \pm 0.18^{\mathrm{b}}$ & $6.66 \pm 0.06^{\mathrm{b}}$ & $6.40 \pm 0.15^{\mathrm{b}}$ & $6.13 \pm 0.07^{\mathrm{b}}$ \\
3 Extract & 125 & $5.32 \pm 0.09$ & $7.84 \pm 0.21$ & $8.19 \pm 0.31$ & $7.57 \pm 0.20^{\mathrm{a}}$ & $6.87 \pm 0.06^{\mathrm{a}}$ & $6.45 \pm 0.15^{\mathrm{b}}$ & $5.90 \pm 0.18^{\mathrm{b}}$ \\
4 Extract & 250 & $4.91 \pm 0.16$ & $8.06 \pm 0.06^{\mathrm{a}}$ & $8.14 \pm 0.18^{\mathrm{a}}$ & $7.70 \pm 0.20^{\mathrm{a}}$ & $7.28 \pm 0.24^{\mathrm{a}}$ & $6.85 \pm 0.28$ & $6.65 \pm 0.25$ \\
5 Extract & 500 & $4.94 \pm 0.09^{\mathrm{a}}$ & $7.29 \pm 0.15^{\mathrm{b}}$ & $7.81 \pm 0.13$ & $7.27 \pm 0.16$ & $6.95 \pm 0.14$ & $6.61 \pm 0.14$ & $6.44 \pm 0.13$ \\
\hline
\end{tabular}

$\mathrm{n}=5 ; \quad{ }^{\mathrm{a}} \mathrm{P}<0.05$ compared to Diclofenac; ${ }^{\mathrm{b}} \mathrm{P}<0.05$ compared to Normal saline; Data presented as mean \pm SEM

Table 5: Effect of hydroethanolic extract of Cov-Pla 2 on rectal temperature in Brewer's yeast-induced pyrexia in

\begin{tabular}{|c|c|c|c|c|c|c|}
\hline \multicolumn{7}{|c|}{ rats } \\
\hline Group/Treatment & $\begin{array}{l}\text { (Dose } \\
\mathrm{mg} / \mathrm{kg} \text { ) }\end{array}$ & $5 \mathrm{~min}$ & $1 \mathrm{~h}$ & $2 \mathrm{~h}$ & $3 \mathrm{~h}$ & $4 \mathrm{~h}$ \\
\hline 1. Normal saline & $10 \mathrm{~mL} / \mathrm{kg}$ & $36.76 \pm 0.24$ & $37.16 \pm 0.20$ & $36.98 \pm 0.27$ & $37.32 \pm 0.25$ & $36.64 \pm 0.23$ \\
\hline 2. Aspirin & 10 & $36.74 \pm 0.22$ & $37.22 \pm 0.06$ & $36.82 \pm 0.31$ & $36.64 \pm 0.16^{\mathrm{b}}$ & $36.88 \pm 0.12$ \\
\hline 3. Extract & 125 & $36.42 \pm 0.36$ & $37.18 \pm 0.09$ & $36.08 \pm 0.26^{\mathrm{b}}$ & $36.06 \pm 0.13^{\mathrm{ab}}$ & $37.20 \pm 0.26$ \\
\hline 4. Extract & 250 & $35.78 \pm 0.27^{\mathrm{ab}}$ & $37.02 \pm 0.30$ & $37.06 \pm 0.31$ & $36.28 \pm 0.25^{\mathrm{b}}$ & $35.88 \pm 0.26^{\mathrm{a}}$ \\
\hline 5. Extract & 500 & $36.62 \pm 0.27$ & $36.92 \pm 0.09^{\mathrm{a}}$ & $35.94 \pm 0.08^{\mathrm{ab}}$ & $36.24 \pm 0.31^{\mathrm{b}}$ & $37.08 \pm 0.10$ \\
\hline
\end{tabular}

Therefore, the analgesic activity of the extract may be peripherally mediated via the inhibition of synthesis and releases of prostaglandins. Pain induced by thermal stimulus of the hot plate is specific for centrally mediated nociception [24]. The authors from that study found that the ability of an extract to increase the reaction latency to thermally induced pain in mice by the hot plate is an indication of its central analgesic activity. 
Findings from this present study correlated with the findings of [23], where reaction time was seen to increase in a dose dependent (125$500 \mathrm{mg} / \mathrm{kg}$ ) manner over time.

The anti-inflammatory activity of the polyherbal extract (Cov Pla-2) was evaluated in this study using the egg albumin rat paw oedema test. The paw size of all the treated groups in this test decreased from the first hour post-oedema induction in a dose-dependent manner $(125-500 \mathrm{mg} / \mathrm{kg})$ as compared to the control group (Table 4). Oedema reduction in the treated groups increased with time, a finding that is supported by a previous study involving inhibition of egg albumin-induced oedema by an extract [25]. Our extract may have elicited its anti-inflammatory effect by inhibiting the release of histamine and 5-HT, two mediators that are released by egg albumin [26].

The rats treated with the extract showed a reduction in rectal temperature in a dose-dependent (125-500 $\mathrm{mg} / \mathrm{kg}$ ) manner as early as $2 \mathrm{~h}$ post hyperthermia-induction (Table 5), when compared with control animals. The ability of an extract with antipyretic activity to also reduce rectal temperature, as also shown in this present study, was similarly shown in an earlier study [27]. These results support the use of the extract as an antipyretic for the treatment of fever.

Conclusion. This study demonstrated the antinociceptive, anti-inflammatory and antipyretic properties of the hydroethanolic polyherbal extract using several models (chemical and thermal) of nociception in mice and rats. The findings suggest their possible use to treat inflammation and pain associated with Covid-19 disease.

Acknowledgements. The authors acknowledge the technical assistance of $\mathrm{Mr}$. Luka Wazoh, Mr. Bulus Diyen, Mr. Azi Sunday, Mr. Madaki Hoelleng Joshua and Miss. Joy Muplang Alexander, staff of the Department of Pharmacology \& Toxicology,
University of Jos, Nigeria. This research was funded by the Plateau State Government and applied by the Plateau State Research Team on Covid-19 and Other Infectious Diseases, Jos, Plateau State, Nigeria.

\section{REFERENCES}

1. Huang C, Wang Y, Li X, Ren L, Zhao J, Hu, Y, et al. Clinical features of patients infected with 2019 novel coronavirus in Wuhan, China. Lancet 2020;395(10223):497-506.

2. WHO. (2004). WHO Guidelines on Safety Monitoring of Herbal Medicines in Pharmacovigilance Systems. Geneva, Switzerland: World Health Organization. Available at https://apps.who.int/iris/bitstream/handle/10665/4303 4/9241592214_eng.pdf?sequence $=1 \&$ isAllowed $=y$

3. Zheng YY, Ma Y, Zhang JY, Xie X. COVID-19 and the cardiovascular system. Nat Rev Cardiol. 2020;17(5):259-260.

4. Lai CC, Shih T-P, Ko W-C, Tang H-J, Hsueh P-R. Severe Acute Respiratory Syndrome Coronavirus 2 (SARS-CoV-2) and Corona Virus Disease-2019 (COVID-19): the Epidemic and the Challenges. Int. J. Antimicrob. Agents. 2020;55(3):105924.

5. Sadiq M, Aziz OA, Kazmi U, et al. Multisystem inflammatory syndrome associated with COVID-19 in children in Pakistan. Lancet Child Adolesc Health. 2020;S2352-4642(20)30256-X.

6. Panigrahy D, Gilligan MM, Huang S, Gartung A, Cortés-Puch I, Sime PJ, et al. Inflammation resolution: a dual-pronged approach to averting cytokine storms in COVID-19? Cancer and Metastasis Rev. 2020;39:337-340.

7. Amagon KI, Wannang NN, Iliya HA, Ior LD, ChrisOtubor GO. Flavonoids Extracted from Fruit Pulp of Cucumis metuliferus Have Antiviral Properties. $\mathrm{Br}$. J. Pharm. Res. 2012;2(4):249-258.

8. Sharma S, Baboota S, Amin S, Mir SR. Ameliorative effect of a standardized polyherbal combination in methotrexate-induced nephrotoxicity in the rat. Pharm Biol. 2020;58(1):184-199.

9. Parasuraman S, Thing G, Dhanaraj S. Polyherbal formulation: concept of Ayurveda. Pharmacogn Rev. 2014;8(16):73-80.

10. Almeida RN, Navarro DS, Barbosa FJM. Plants with Central Analgesic Activity. Phytomedicine. 2001;8:310-322. 
11. Amos S, Kolawole E, Akah P, Wambebe C, Gamaniel K. Behavioural effects of the aqueous extract of Guiera senegalensis in mice and rats. Phytomedicine 2001;8(5):356-361.

12. National Research Council: A Guide for the Care and Use of Laboratory Animals. In: A Report of the Institute of Laboratory Animal Resources Committee on Care and Use of Laboratory Animals. National Institutes of Health, National Academy Press, Washington, DC, 1985, Publication No. 85-23.

13. Lorke D. A New Approach to Practical Acute Toxicity Testing. Arch Toxicol. 1983;54:275-287.

14. Adeyemi OO, Akindele AJ. Evaluation of the antiinflammatory activity of the aqueous leaf extract of Byrsocarpus coccineus. Fitoterapia 2007;78:25-28.

15. Su JY, Li QC, Zhu L. Evaluation of the in vivo antiinflammatory activity of a flavone glycoside from Cancrinia discoidea (Ledeb.) Poljak. EXCLI J. 2011;10:110-116.

16. Koster R, Anderson M, De Beer EJ. Acetic acid Analgesic Screening. Federation Proc. 1959;18:412.

17. Jacob JJC, Ramabadran K. Enhancement of a Nociceptive Reaction by Opiate Antagonists in Mice. Br J Pharmacol.1978;64:91-98.

18. Omisore NO, Adewunmi CO, Iwalewa EO, Ngadjui J. Antinociceptive and anti-inflammatory effects of Dorstenia barteri (Moraceae) leaf and twig extracts in mice. J Ethnopharmacol. 2004;95:7-12.

19. Loux JJ, Depalma DD, Yankell SL. Antipyretic testing of aspirin in rats. Toxicol Appl Pharmacol. 1972;22:672-675.

20. Singh S, Majumdar DK. Anti-nociceptive activity of Ocimum sanctum and its possible mechanism of action. Int J Pharmacogn. 1995; 33:188-192.
21. Zakaria ZA, Abdul-Ghani ZDF, Raden-Mohd-Nor RNS, Kumar GH, Ghani ZDFA, Sulaiman MR, et al. Anti-nociceptive, anti-inflammatory, and antipyretic properties of an aqueous extract of Dicrariopteris linearis leaves in experimental animal models. $J$ Nat Med. 2008;62:179-187.

22. Mallam D, Anuka JA, Zezi AU, Magaji MG, Chindo BA, Sani MB. Analgesic and Anti-Inflammatory activities of in Mice and Rats. IOSR J. Pharm. 2016;6(8):1-7.

23. Berkenkopf JW, Weichman BM. Production of prostacyclin in mice following intraperitoneal injection of acetic acid, phenylbenzoquinone and zymosan: its role in the writhing response. Prostaglandins 1988;36(5):693-709.

24. Akindele AJ, Oladimeji-Salami JA, Usuwah BA. Antinociceptive and Anti-Inflammatory Activities of Telfairia occidentalis Hydroethanolic Leaf Extract (Cucurbitaceae).J Med Food. 2015;18(10):1157-1163.

25. Nwafor PA, Jacks TW, Ekanem AU. Analgesic and anti-inflammatory effects of methanolic extract of Pausinystalia mecroceras stem bark in rodents. $J$ Pharmacol. 2007;3:86-90.

26. Adeyemi OO, Okpo SO, Okpaka O. The analgesic effect of the methanolic extract of Acanthus montanus. J Ethnopharmacol. 2004;90(1):45-48.

27. Tag H, Namsa ND, Mandal M, Kalita P, Das AK, Mandal SC. Antipyretic and antibacterial activity of Chloranthus erectus (Buch.-Ham.) Verdcourt leaf extract: A popular folk medicine of Arunachal Pradesh. Indian J Pharmacol. 2010;42(5):273-276. 